\title{
Effects of Density Gradient Sperm Preparation on Semen Parameters and Acrosomal Status
}

\author{
ilknur Keskin 1,3, Seda Karabulut ${ }^{2,3}$ \\ ${ }^{1}$ Medipol University, School of Medicine, İstanbul, Turkey \\ ${ }^{2}$ Medipol University, International School of Medicine, İstanbul, Turkey \\ ${ }^{3}$ Regenerative and Restorative Medicine Research Center (REMER), İstanbul, Turkey
}

\begin{abstract}
Summary
Abstract

Introduction: The aim of this study was to observe changes in sperm parameters after density gradient sperm preparation. These data will help to decide upon preparation technique and to predict the outcome of semen parameters after using this technique.

Methods: A total of 1402 men who were screened for infertility at the Florence Nightingale Hospital in vitro fertilization clinic between April 2011 and October 2016 were analyzed. Semen analysis was performed according to World Health Organization 2010 guidelines before and after semen preparation. Samples with $<1 \mathrm{mil} / \mathrm{mL}$ sperm concentration were prepared using the density gradient centrifugation technique and the semen parameters (sperm concentration, total motility, progressive motility, normal morphology rate, and normal acrosomal status rate) were analyzed.

Results: Although sperm concentration was reduced, the total motility, progressive motility, and normal morphology rate were higher after density gradient semen preparation. Sperm concentration decreased by $37.49 \%$ after semen preparation $(p=0.01)$. Total motility rate increased significantly, by $21.47 \%$ (66.1\% before and $87.57 \%$ after semen preparation), progressive motility rate increased by $28.12 \%$ (11.45\% before and $39.57 \%$ after semen preparation), normal morphology rate increased by $5 \%$ (3\% before and $8 \%$ after semen preparation), and normal acrosomal status rate increased by $14 \%$ (62\% before and 76\%) after semen preparation $(\mathrm{p}<0.01)$

Discussion and Conclusion: According to the results of this study, the sperm parameters of total motility, progressive sperm motility, normal morphology, and normal acrosomal status rate increased, but sperm concentration decreased after density gradient sperm preparation. These data will help the specialist to decide upon the sperm preparation technique to be used in assisted reproduction and to predict the outcome of semen parameters after using this technique.
\end{abstract}

Keywords: Density gradient; infertility; sperm.

\section{Dansite Gradyan Sperm Yıkama Yönteminin Sperm Parametreleri ve Akrozomal Duruma Etkileri}

Giriş ve Amaç: Çalışmanın amacı sperm parametrelerinin yoğunluk gradyan yöntemi ile yıkanmasının sperm sonuçlarının etkisini araştırmak ve uzmanlara bu yöntem ile yıkama sonrasında sonuçları öngörme imkanı verebilmektir.

Yöntem ve Gereçler: 04.2011- 10.2016 tarihleri arasında Florence Nightingale Hastanesi, Yardımla Üreme Merkezi'ne infertilite araştırması nedeniyle başvuran 1402 erkek çalışmaya alınmıştır. Sperm hazırlama öncesi ve sonrasında semen analizleri WHO 2010'a göre yapılmıştır. Sperm konsantrasyonu <1 mil/ml nin altındaki örnekler dansite gradyan yöntemiyle hazırlanmış ve semen parametreleri (sperm konsantrasyonu, toplam motilite, progresif motilite, normal morfoloji ve normal akrozom yapısı oranları analiz edilmiştir.

Correspondence (Illetişim): Illknur Keskin, M.D. Medipol University Faculty of Medicine, İstanbul;

Regenerative and Restorative Medicine Research Center (REMER) Istanbul, Turkey

Phone (Telefon): 4448544 E-mail (E-posta): ilknurkeskin@medipol.edu.tr

Submitted Date (Başvuru Tarihi): 09.03.2017 Accepted Date(Kabul Tarihi): 06.04.2017

Copyright 2017 SBÜ Haydarpaşa Numune Eğitim ve Araştırma Hastanesi | Bu CC BY-NC lisansı altında açık erişimli bir makaledir.

This is an open access article under the CC BY-NC-ND license (http://creativecommons.org/licenses/by-nc/4.0/). 


\begin{abstract}
Bulgular: Yoğunluk gradyan yöntemi sonrasında sperm konsantrasyonu azalmasına rağmen total motilite, progresif motilite, normal morfoloji ve normal akrozomal yapı oranları artmış olarak bulunmuştur $(p<0.05)$. Sperm konsantrasyonu parametresinde \%37.49 lük anlamlı bir azalma belirlenmiştir. Toplam motilite oranında \%21.47'lik anlamlı bir artış (yıkama öncesi \%66.1 ve yıkama sonrası \%87.57) after semen preparation, progresif motilite oranında \%28.12'lik bir artış (yıkama öncesi \%11.45 ve yıkama sonrası \%39.57), normal morfoloji oranında \%5'lik bir artış (yıkama öncesi \%3 ve yıkama sonrası \%8), ve normal akrozomal yapı oranında \%14'lük bir artış yıkama öncesi \%62 ve yıkama sonrası \%76), belirlenmiştir $(p<0.05)$.

Tartışma ve Sonuç: Çalışmanın bulguları doğrultusunda yoğunluk gradyanı yöntemi sonrasında toplam motilite, progresif motilite, normal morfoloji ve normal akrozomal yapı oranları anlamlı derecede artmış ancak sperm konsantrasyonu anlamlı derecede azalmış olarak belirlenmiştir $(p<0.05)$. Bulgular, uzmanlara yöntem sonrasında parametreleri öngörme ve buna göre yardımla üreme tekniklerinde sperm hazırlama yöntemini seçmekte yardımcı olacaktır.
\end{abstract}

Anahtar sözcükler: Dansite gradyan; infertilite; sperm.

$M$ ale factor infertility is about \%30-50 of all infertility cases ${ }^{[1]}$. In these cases sperm parameters are lower than the accepted values determined by the authorities like World Health Organization (WHO). Nearly no proven treatment strategy is present to overcome this situation. Assisted reproductive techniques (ART-intrauterine insemination/classic in vitro fertilization/intracytoplasmic sperm injection) are the techniques that are used for couples facing this problem. Before sperm can be used in ART, it must first be processed. The goal of processing is to select motile and morphologically and genetically normal spermatozoa having higher fertilizing ability ${ }^{[2-4]}$. At the same time, cellular debris must be removed, including round cells, epithelial cells, white blood cells as well as immature or morphologically abnormal sperm cells that are immotile or have poor motility. There are several techniques that are used to prepare the sperm for ART. These techniques include swim up, density gradient and centrifugation. Density gradient technique is the centrifugation technique of neat semen on layers of specific solutions having different densities. A mature and morphologically normal sperm cell has a density of $1.10 \mathrm{~g} / \mathrm{mL}$ whereas an immature and morphologically abnormal spermatozoon has a lower density between 1.06 and $1.09 \mathrm{~g} / \mathrm{mL}$. During centrifugation, sperm cells are placed at the level that suitable for its density. As a result, the resulting interphases between seminal plasma and the high and low density layers, containing the leukocytes, dead cells, cell debris and morphologically abnormal sperm with poor motility are discarded. The highly motile, morphologically normal, viable spermatozoa form a pellet at the bottom of the tube ${ }^{[3,4]}$.These layers behave as filters to eliminate the dead and bad quality sperm cells during the centrifugation. After washing the pellet several times with specific solutions the sperm population is used for assisted reproductive techniques. The concentration of the semen decreases because of the selection procedure in this technique and this may be a disadvantage when the semen concentration is poor. Some prefer to use swim-up procedure in this situation in which the semen is put in a solution and after incubation the sperm population that swim above the layer is used. Also the swim-up technique has several advantages on other techniques like less time-consuming and needs less effort and no device. But density gradient also have several advantages over swim-up method like more decreased DNA fragmentation levels as stated in several studies ${ }^{[5-8]}$. DNA fragmentation is an important aspect for fertility as the DNA status of the sperm cell reflects half the DNA status of the zygote. Considering these data, although sperm preparation can be accomplished using a number of different techniques ${ }^{[3,4]}$. Research mostly shows that density gradient method consistently produces samples of the highest quality required for intrauterine insemination and for in vitro fertilization (IVF), which explains why it is the preferred processing method ${ }^{[9-15]}$.

Semen parameters including the concentration, motility (total motility and progressive motility) and morphology is observed in the previous study to see the differences before and after the preparation. Besides this the acrosomal status is also analyzed to see the effect of DG semen preparation on the acrosomal status of the sperm population. Acrosomal status is an important issue for the fertilizing capacity of a sperm cell because it carries the enzymes used to penetrate and fertilize the oocyte. It contains high amounts of acrosin, which is essential for gamete fusion, particularly for binding to, and penetration of, the zona pellucida. In addition, its activation from proacrosin seems to be associated with the capacitation process. Furthermore, it might facilitate cervical mucus penetration and intrauterine sperm migration by releasing kinins from kininogen, as well as participating in the acrosome reaction and in chromatin decondensation in the oocyte. Considering these functions of the acrosome during the process of fertilization, the morphology and functional integrity of the acrosome in ejaculated human spermatozoa are of fundamen- 
tal importance in attachment, species-specific binding and zona penetration preceding gamete fusion ${ }^{[16]}$.

In the daily practice the specialist decide the technique especially by considering the quality of the semen but he/she also should consider the technique's benefits for the fertility treatment used. The most beneficial and physiological technique should be used.

The aim of this study is to observe the changes in the sperm parameters (concentration, total motility, progressive motility, morphology and acrosomal status) after density gradient sperm preparation. The data will help the specialist to decide the preparation technique and to predict the outcome of semen parameters after using this technique. The results obtained will also add valuable data to the literature about the effects of DG preparation on acrosomal status of the sperm population.

\section{Materials and Methods}

\section{Study Design}

1402 subfertile men that attend our fertility clinic for fertility investigation between 04.2011- 10.2016 were analyzed. All subjects were male volunteers aged $18-56$ years. Samples having $<1 \mathrm{mil} / \mathrm{ml}$ sperm concentration were included in the study. These patients were selected based on normal semen parameters according to the WHO 2010 criteria for concentration, motility and morphology. Each patient had at least two of the 4 sperm parameters normal i.e. sperm concentration, total motility, progressive motility or morphology, to be included in the study. Also all samples were checked for presence of leukocytospermia. Samples with $>1 \times 10^{6}$ white blood cells $/ \mathrm{mL}$ were excluded from the study. Also the acrosomal status of the samples were determined by Kruger's strict criteria that is not considered before in the literature.

The Ethical Committee of Medipol University, Ethical Commitee, approved this study on 16.02.2017 (decision number 10840098-604.01.01-E.4265).

\section{Semen Analysis}

Semen analysis was performed according to WHO criteria (WHO, 2010). Specimens were collected by masturbation after 3-7 days of sexual abstinence. Semen analysis was performed with a phase contrast (Olympus, CX40) microscope after liquefaction. Liquefaction time, appearance, volume, $\mathrm{pH}$, and viscosity of the semen samples were noted. Samples were analysed for sperm concentration $(\mathrm{mil} / \mathrm{ml})$, forward progressive sperm motility (\%), total motility (\%) and normal morphology rate (\%) before and after semen preparation.

\section{Semen Preparation}

The semen samples were prepared by two-layer (90\% and 45\%) discontinuous PureSperm (Nidacon, Molndal, Sweden) gradient technique. One $\mathrm{mL}$ of the semen sample is added on two layers of the solution and centrifuged at 400 $\mathrm{G}$ for $20 \mathrm{~min}$. Then $400 \mu \mathrm{l}$ of the pellet were aspirated from the bottom of the tube (Falcon 2095, Becton Dickinson, NJ, USA). The pellet is put in a new tube and suspended in 5 $\mathrm{mL}$ of PureSperm Wash solution. The suspension was centrifuged at $500 \mathrm{G}$ for $6 \mathrm{~min}$. The supernatant was discarded and centrifugation was repeated once more. Finally the supernatant was discarded again and the pellet was suspended in $0.5 \mathrm{~mL}$ of medium for further examination.

\section{Statistical Analysis}

SPSS for Windows 16.0 software package was utilised for the statistical analysis. Mann Whitney $U$ test was used to evaluate the rates and differences between the groups. The results were evaluated in $95 \%$ confidence interval and the statistical significance was defined as, $\mathrm{p}<0.05$.

\section{Results}

The mean age of the men were calculated as $37 \pm 6.53$ (between 18-56). Semen parameters (mean \pm SD) were evaluated for sperm concentration $\left(\mathrm{X} 10^{6} / \mathrm{mL}\right)(78.67 \pm 81.3 \%)$; presence of round cells $\left(1.1 \times 10^{6} / \mathrm{mL}\right)$; negative for Leukoctyospermia; sperm morphology $(3 \pm 4 \%)$, percent total motility $(66.1 \pm 19.85 \%)$ and percent progressive motility $(11.45 \pm 13.55 \%)$ and acrosomal status $(62 \pm 23.5 \%)$. Figure 1 lists the semen quality parameters including concentration, percent motility, total motility, progressive motility, normal morphology and normal acrosomal status rates be-

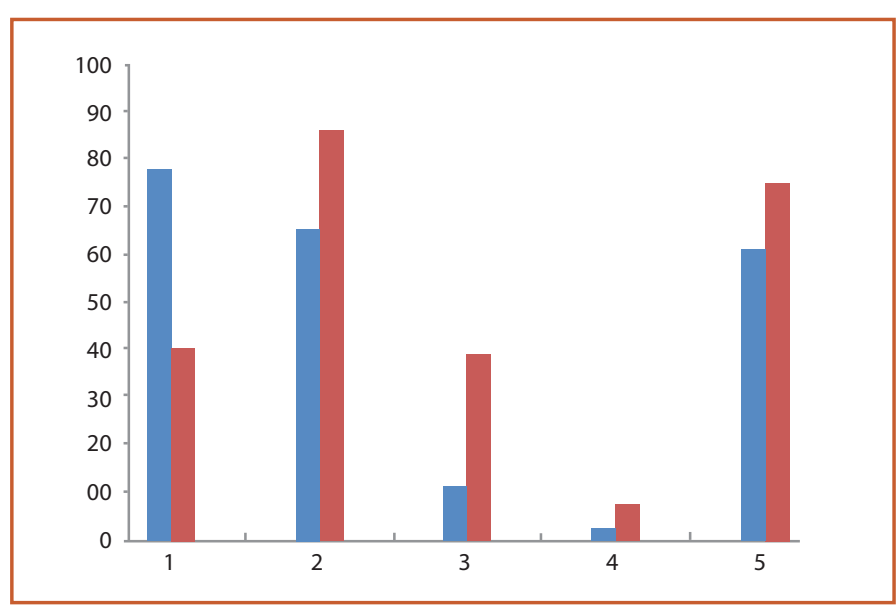

Figure 1. Differences between sperm parameters before (blue) and after (red) sperm preparation by density gradient centrifugation. I: Concentration (mil/mL); 2: Total motility rate (\%); 3: Progressive motility rate (\%); 4: Normal morphology rate (\%); 5: Normal acrosomal status rate (\%). 
fore and after separation by density gradient preparation.

\section{Sperm Concentration}

The sperm concentration was decreased after separation by $\mathrm{dg}(78.67 \% \pm 81.3$ before and $41.18 \% \pm 44.09$ resp.) The difference between the pre-wash and prepared samples $(-37.49 \%)$ was statistically significant $(p=0.01)$.

\section{Total Motility}

We found a significant difference in percent total motility $(66.1 \pm 19.85 \%$ before and $87.57 \pm 14.51 \%$ after) between pre-wash and prepared samples after sperm preparation prepared by dg $(p=0.02)$. After DG significantly higher motility $(+21.47 \%)$ was obtained in samples.

\section{Progressive Motility}

We found a significant difference in percent progressive motility $(11.45 \pm 13.55 \%$ before and $39.57 \pm 21.45 \%)$ between pre-wash and prepared samples after sperm preparation prepared by $d g(p=0.02)$. significantly higher progressive motility $(+28.12 \%)$ was seen in samples after DG.

\section{Normal Morphology}

A significant difference in percent normal morphology (3\% \pm 4 before and $8 \% \pm 3$ ) between pre-wash and prepared samples after sperm preparation prepared by DG is obtained $(p=0.01)$. After DG significantly higher normal morphology rate $(+5 \%)$ was seen.

\section{Acrosomal Status}

Difference in percent normal acrosomal status $(62 \pm 23.5 \%$ before and $76 \pm 13 \%$ ) between pre-wash and prepared samples after sperm preparation is also significant $(p=0.015)$. A higher normal acrosomal status rate $(+14 \%)$ was seen after DG.

\section{Discussion}

Effects of density gradient semen preparation method on basic four sperm parameters concentration, motility (total motility and progressive motility), morphology is observed in the previous study to see the differences before and after the preparation. Besides this the acrosomal status is also analyzed to see the effect of DG semen preparation on the acrosomal status of the sperm population.

According to our data, sperm concentration is decreased as the progressive sperm motility, total motility and normal morphology rates increased after density gradient sperm preparation. The procedure used seems to eliminate dead and bad quality sperm cells strictly but as a result the concentration of the samples obtained decreases. This becomes a disadvantage when poor quality sperm samples are of concern. But besides this the motility and morpholo- gy parameters are improved reflecting the improvement of the semen quality. This is important especially in ART techniques because in OAT patients this technique improves sperm quality and helps to choose the better cells for the procedure. This findings are in accordance with the findings of Noguchi et al showing that the centrifugation on density gradient technique enhances motility, membrane integrity and in vitro fertilizing ability of frozen-thawed boar sperm [17]. Also Chiamchanya et al., ${ }^{[18]}$ reported a significant improvement in sperm motility (both rapid and progressive) and percentage of sperm with normal morphology. In this study compared with the other products PureSperm gave the best results. Also in a study by Malvezzi et al., ${ }^{[19]}$ DG sperm preparation with three different media enhanced the semen parameters significantly similar with our data.

There is no study in the literature studying the acrosomal status of the semen samples before and after semen preparation. Acrosomal status is an important issue to assess the fertilizing capacity of a sperm because it carries the enzymes used to penetrate and fertilize the oocyte and have role in capacitation sand acrosome reaction ${ }^{[16]}$. We found that the normal acrosomal status rates also enhanced after DG preparation significantly. When the prepared sperm is used fur IUI or classical IVF it is more important because the sperm population fertilizes the oocytes by themselves. Besides this it is also important for use in ICSI procedure because acrosome is needed for the activation of the oocyte we know that globoozoospermic sperm samples having no acrosome on the sperm head) have very little but usually no fertilizing capacity even if they are used in ICSI.

The data will help the specialist to decide the preparation method for the semen sample. Specialist should be aware of the outcome of the technique used but besides this the techniques' effects on acrosomal status should also be considered for t he outcome. The only aim should not be only to have motile and morphologically normal sperm with the highest concentration but should also aim the overall success of the sperm and of the treatment.

More studies evaluating the overall results of the technique should be planned for future research.

Ethics Committee Approval: Ethics Committee of Medipol University, approval number: 10840098-604.01.01-E.4265.

Peer-review: Externally peer-reviewed.

Authorship Contributions: Concept: I.K., S.K.; Design: I.K., S.K.; Data Collection or Processing: I.K., S.K.; Analysis or Interpretation: I.K., S.K.; Literature Search: I.K., S.K.; Writing: I.K., S.K.

Conflict of Interest: None declared. 
Financial Disclosure: The authors declared that this study received no financial support.

\section{References}

1. Speroff L, Glass RH, Kase NG. Infertility. In: Clinical gynecologic endocrinology and infertility. 6th ed. Baltimore, USA: Lippincott Williams-Wilkins; 1999. p. 201-46.

2. Allamaneni SS, Agarwal A, Rama S, Ranganathan P, Sharma RK. Comparative study on density gradients and swim-up preparation techniques utilizing neat and cryopreserved spermatozoa. Asian J Androl 2005;7:86-92.

3. Beydola T, Sharma RK, Lee W, Agarwal A. Sperm preparation and selection techniques. In: Rizk B, Aziz N, Agarwal A, editors. Male Infertility Practice. New Delhi: Jaypee Brothers Medical Publishers; 2013. p. 244-51.

4. Boomsma CM, Heineman MJ, Cohlen BJ, Farquhar C. Semen preparation techniques for intrauterine insemination. Cochrane Database Syst Rev 2004:CD004507.

5. Donnelly ET, O'Connell M, McClure N, Lewis SE. Differences in nuclear DNA fragmentation and mitochondrial integrity of semen and prepared human spermatozoa. Hum Reprod 2000;15:1552-61.

6. Marchetti C, Obert G, Deffosez A, Formstecher P, Marchetti P. Study of mitochondrial membrane potential, reactive oxygen species, DNA fragmentation and cell viability by flow cytometry in human sperm. Hum Reprod 2002;17:1257-65.

7. Sakkas D, Manicardi GC, Tomlinson M, Mandrioli M, Bizzaro D, Bianchi PG, et al. The use of two density gradient centrifugation techniques and the swim-up method to separate spermatozoa with chromatin and nuclear DNA anomalies. Hum Reprod 2000;15:1112-6.

8. Amiri I, Ghorbani M, Heshmati S. Comparison of the DNA Fragmentation and the Sperm Parameters after Processing by the Density Gradient and the Swim up Methods. J Clin Diagn Res 2012;6:1451-3.

9. Jayaraman V, Upadhya D, Narayan PK, Adiga SK. Sperm pro- cessing by swim-up and density gradient is effective in elimination of sperm with DNA damage. J Assist Reprod Genet 2012;29:557-63.

10. Zini A, Finelli A, Phang D, Jarvi K. Influence of semen processing technique on human sperm DNA integrity. Urology 2000;56:1081-4.

11. Zini A, Nam RK, Mak V, Phang D, Jarvi K. Influence of initial semen quality on the integrity of human sperm DNA following semen processing. Fertil Steril 2000;74:824-7.

12. Bungum $M$, Spanò $M$, Humaidan $P$, Eleuteri $P$, Rescia $M$, Giwercman A. Sperm chromatin structure assay parameters measured after density gradient centrifugation are not predictive for the outcome of ART. Hum Reprod 2008;23:4-10.

13. Brahem S, Mehdi M, Elghezal H, Saad A. Semen processing by density gradient centrifugation is useful in selecting sperm with higher double-strand DNA integrity. Andrologia 2011;43:196-202.

14. Brahem S, Mehdi M, Landolsi H, Mougou S, Elghezal H, Saad A. Semen parameters and sperm DNA fragmentation as causes of recurrent pregnancy loss. Urology 2011;78:792-6.

15. Enciso M, Iglesias M, Galán I, Sarasa J, Gosálvez A, Gosálvez J. The ability of sperm selection techniques to remove single- or double-strand DNA damage. Asian J Androl 2011;13:764-8.

16. Schill WB, Töpfer-Petersen E, Heissler E. The sperm acrosome: functional and clinical aspects. Hum Reprod 1988;3:139-45.

17. Noguchi M, Yoshioka K, Hikono H, Iwagami G, Suzuki C, Kikuchi K. Centrifugation on Percoll density gradient enhances motility, membrane integrity and in vitro fertilizing ability of frozen-thawed boar sperm. Zygote 2015;23:68-75.

18. Chiamchanya C, Kaewnoonual N, Visutakul P, Manochantr $S$, Chaiya J. Comparative study of the effects of three semen preparation media on semen analysis, DNA damage and protamine deficiency, and the correlation between DNA integrity and sperm parameters. Asian J Androl 2010;12:271-7.

19. Malvezzi H, Sharma R, Agarwal A1, Abuzenadah AM, Abu-Elmagd M. Sperm quality after density gradient centrifugation with three commercially available media: a controlled trial. Reprod Biol Endocrinol 2014;12:121. 